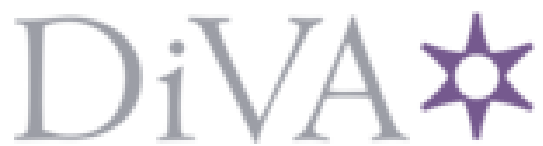

http://www.diva-portal.org

This is the published version of a paper published in .

Citation for the original published paper (version of record):

Martínez-Castro, E. (2020)

Scalable Synthesis of Esp and Rhodium(II) Carboxylates from Acetylacetone and $\mathrm{RhCl}_{3} \cdot \mathrm{xH}_{2} \mathrm{O}$

Organic Process Research \& Development

https://doi.org/10.1021/acs.oprd.ocoo164

Access to the published version may require subscription.

N.B. When citing this work, cite the original published paper.

Permanent link to this version:

http://urn.kb.se/resolve?urn=urn:nbn:se:su:diva-182261 


\title{
Scalable Synthesis of Esp and Rhodium(II) Carboxylates from Acetylacetone and $\mathrm{RhCl}_{3} \cdot \mathrm{XH}_{2} \mathrm{O}$
}

\author{
Elisa Martínez-Castro, Samuel Suárez-Pantiga, and Abraham Mendoza* \\ Cite This: https://dx.doi.org/10.1021/acs.oprd.0c00164 \\ Read Online
}

ABSTRACT: Rhodium(II) carboxylates are privileged catalysts for the most challenging carbene-, nitrene-, and oxo-transfer reactions. In this work, we address the strategic challenges of current organic and inorganic synthesis methods to access these rhodium(II) complexes through an oxidative rearrangement strategy and a reductive ligation reaction. These studies illustrate the multiple benefits of oxidative rearrangement in the process-scale synthesis of congested carboxylates over nitrile anion alkylation reactions, and the impressive effect of inorganic additives in the reductive ligation of rhodium(III) salts.

KEYWORDS: rhodium catalysis, oxidative rearrangement, 1,3-diketone, sigmatropic shift, rhodium(II)

$\mathrm{T}$ otal synthesis has been a major resource to facilitate the supply of scarce substances ${ }^{1}$ and a fertile playground to create and test new chemistries. ${ }^{2}$ Despite the dominance of natural product and pharmaceutical targets in these studies, our group ${ }^{3}$ and others ${ }^{4}$ have used ligands to inspire synthetic innovations. ${ }^{5}$ The synthesis of metal catalysts offers uncharted opportunities for basic research in both organic and inorganic chemistry and can facilitate the introduction of state-of-the-art catalysts in industrial production. In this sense, metal carboxylates have historically played a key role in the development of homogeneous catalysis, particularly in the field of $\mathrm{C}-\mathrm{H}$ functionalization. ${ }^{6}$ Traditional pivalate complexes ${ }^{7}$ have evolved into congested carboxylates to tackle the most challenging transformations. ${ }^{6 c, 2 \mathrm{~d}, 8}$ In particular, the pursuit of aliphatic $\mathrm{C}-\mathrm{H}$ amination ${ }^{9,10}$ resulted in the development in 2004 of $\mathrm{Rh}_{2} \operatorname{esp}_{2} \quad\left(\mathbf{1}\right.$; esp $=\alpha, \alpha, \alpha^{\prime}, \alpha^{\prime}$ tetramethyl-1,3-benzenedipropionic acid) by Du Bois and coworkers (Scheme 1A). ${ }^{11}$ This catalyst displays a double chelate structure with two bis-carboxylate ligands 2 , which stabilize the labile mixed-valence intermediates involved in the catalysis. ${ }^{12}$ $\mathrm{Rh}_{2} \operatorname{esp}_{2}(\mathbf{1})$ has currently been extensively deployed in natural product total synthesis ${ }^{8}$ and is increasingly finding new applications in carbene-, ${ }^{13}$ nitrene-, ${ }^{14}$ and oxo-transfer reactions ${ }^{15}$ due to its unique properties. Moreover, the ligand esp (2) is now widespread in unrelated types of catalysis with palladium, rhenium, ruthenium, copper, cobalt, or bismuth. ${ }^{16}$

Despite its importance, the chemical synthesis of the ligand esp (2) $)^{11,16 a, 17}$ and its rhodium complex $\mathbf{1}^{11}$ have not evolved along their applications. The synthetic strategy toward the congested bis-carboxylate ligand $\mathbf{2}$ is based on the alkylation of isobutyronitrile (3) via the nitrile anion 4 with $m$-xylene dihalides 5 to forge the all-carbon quaternary center in the dinitrile intermediate 6 (see Scheme 1B). ${ }^{11,16 a, 17,18}$ The latter is elaborated to esp (2) through a thermal hydration process. ${ }^{11,16 a, 17}$ The nitrile anion strategy seems to be responsible for the high cost of this ligand as it requires inert conditions, anhydrous solvents, and large amounts of $n$-BuLi to generate LDA on-scale. On the inorganic synthesis side
Scheme 1. Organic and Inorganic Challenges in the Synthesis of $\mathrm{Rh}_{2} \operatorname{esp}_{2}$ (1)

A
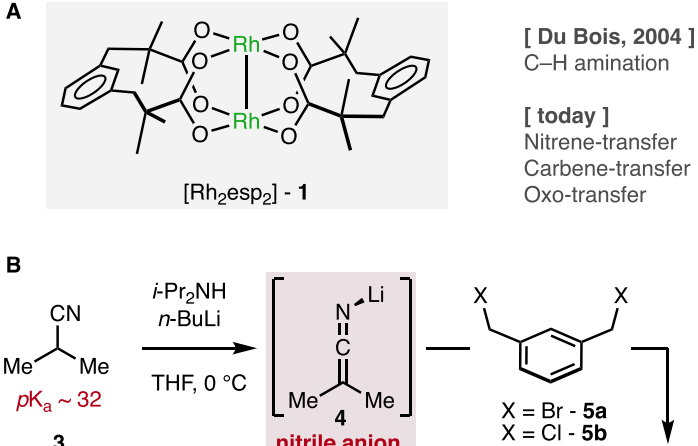

3 nitrile anion $\mathrm{X}=\mathrm{Cl}-5 \mathrm{~b}$<smiles>CC(C)(Cc1ccccc1)Cc1ccccc1</smiles>
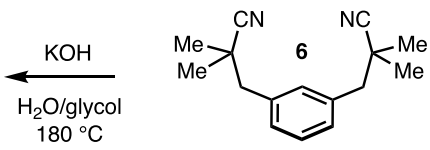

$(67-93 \%)$

$(56-75 \%)$

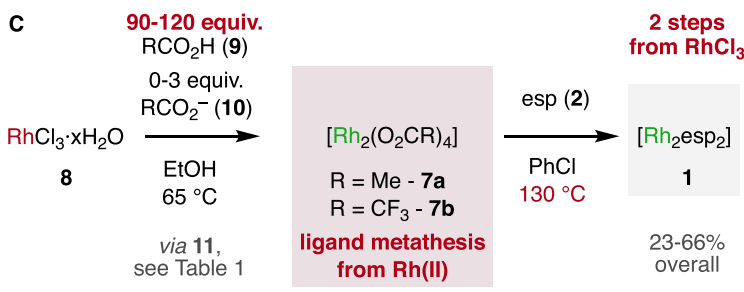

Received: April 6, 2020

Published: April 14, 2020 
(Scheme 1C), $\mathrm{Rh}_{2} \mathrm{esp}_{2}(\mathbf{1})$ is prepared by high-temperature ligand metathesis from rhodium(II) acetate or trifluoroacetate (7a and b) like many other rhodium(II) carboxylates. ${ }^{11,12 \mathrm{~d}, 17 \mathrm{~b}}$ $\mathrm{Rh}_{2}(\mathrm{OAc})_{4}(7 \mathbf{a})$ and $\mathrm{Rh}_{2} \mathrm{TFA}_{4}(7 \mathbf{b})$ are separately obtained by reduction of the accessible rhodium(III) chloride hydrate (8) in the presence of excess carboxylic acid $9 \mathbf{a}$ and $\mathbf{b}$ and a minor amount of its conjugate base $\mathbf{1 0 a}$ and $\mathbf{b} .{ }^{19}$ Rhodium trichloride (8) is the main source of coordination compounds of this metal due to its facile preparation from recycled metallic rhodium and therefore is a more desirable source of advanced rhodium(II) catalysts. ${ }^{20}$

Our recent studies in redox-active carbene transfer ${ }^{21}$ and oxidative rearrangement reactions ${ }^{3 \mathrm{~d}}$ sparked our interest to revise the current organic ${ }^{5,11,16 a, 17}$ and inorganic ${ }^{11}$ synthesis methods toward $\mathrm{Rh}_{2} \mathrm{esp}_{2}$ (1). Namely, our goal was to avoid nitrile anion alkylation in the synthesis of the ligand $\mathbf{2}$ (Scheme 1B) and bypass the preparation of intermediate rhodium(II) carboxylates (i.e., $7 \mathbf{a}$ and $\mathbf{b}$ ) in the preparation of the metal complex 1 (Scheme 1C). ${ }^{11,12,17}$

We questioned whether $\mathrm{Rh}_{2} \mathrm{esp}_{2}$ (1) could be prepared directly from $\mathrm{RhCl}_{3} \cdot x \mathrm{H}_{2} \mathrm{O}$ (8) and esp (2), similarly to the simpler rhodium(II) carboxylates $7 \mathbf{a}$ and $\mathbf{b} .{ }^{11,12,17,22-27}$ In the classic synthesis by Wilkinson of $\mathrm{Rh}_{2}(\mathrm{OAc})_{4}$ (7a; Scheme 1C) ${ }^{19}$ rhodium(III) chloride 8 is reduced by ethanol in the presence of 90-120 equiv of the acetic acid ligand and small amounts of sodium acetate. ${ }^{19 \mathrm{~d}}$ In fact, acidic conditions are commonly used to reduce rhodium(III) using alcohols $\left(E^{0}\{\mathrm{Rh}(\mathrm{III})-\mathrm{Rh}(\mathrm{II})\}=0.7 \mathrm{~V}\right.$ vs $\left.\mathrm{SHE}\right),{ }^{28,29}$ and this principle has not been questioned since the early work by Wilkinson. ${ }^{19}$ This is due to the over-reduction to rhodium(0) (nano)particles that occurs in basic media with excess sodium acetate. $^{30,31}$ Although the detailed mechanism for the synthesis of $\mathrm{Rh}_{2}(\mathrm{OAc})_{4}(7 \mathrm{a})$ remains unknown, a recent study revealed the key intermediacy of the tetranuclear chloride-bridged intermediate 11 (Table 1) that evolves into $\mathrm{Rh}_{2}(\mathrm{OAc})_{4}(7 \mathbf{a})$ upon addition of base. ${ }^{30}$

In our case, the direct reaction of esp (2) and $\mathrm{RhCl}_{3} \cdot x \mathrm{H}_{2} \mathrm{O}$ (8) under the conventional acidic conditions presented above $^{19}$ results in extensive formation of rhodium black, even in the presence of 10-fold excess of the esp ligand (2; Table 1; entry 1). This result points to the particularly rapid aggregation of the rhodium intermediates facilitated by the chelating ability of esp (2). We reasoned that the control of the relative reduction rate of rhodium(III) chloride 8 and the polynuclear rhodium(II) intermediates involved (see 11) was key to limit over-reduction. In principle, the reduction potential of rhodium(III) and the stability of multinuclear intermediates depend on their anionic ligands, which would allow cost-effective inorganic additives to control this process without large excess of elaborate carboxylates. ${ }^{19}$ It was observed that in acidic thermal conditions the ligand 2 undergoes esterification by ethanol, which may be the reason for the large excess of ligand employed in current methods. ${ }^{19}$ This finding invited exploration of basic anions that would inhibit ligand depletion as well as stabilize the rhodium(II) intermediates likely involved. ${ }^{30}$ In agreement with previous studies, small quantities of base were unsuccessful (entries 2, 3). ${ }^{19}$ However, the addition of more than 2 equiv results in a drastic improvement (entry 4), which may indicate that a carboxylate dianion is involved, in stark contrast with previous syntheses. ${ }^{19}$ Other organic and inorganic bases perform variably (entries 5-9) with large influence of the countercation (entry 9-11). $\mathrm{Li}_{2} \mathrm{CO}_{3}$ offers the best balance between
Table 1. Optimization of the Direct Synthesis of $\mathrm{Rh}_{2} \operatorname{esp}_{2}(1)$ from $\mathrm{RhCl}_{3} \cdot \mathrm{xH}_{2} \mathrm{O}(8)$

\begin{tabular}{|c|c|c|c|c|}
\hline esp (2) & $\begin{array}{c}\mathrm{RhCl}_{3} \cdot \mathrm{xH}_{2} \mathrm{O}(8) \\
\text { additive }\end{array}$ & $\begin{array}{c}{\left[\mathrm{Rh}_{2} \mathrm{esp}_{2}\right]} \\
\mathbf{1}\end{array}$ & $\begin{array}{l}\text { Me } 20 \\
\text { stability } \\
\text { control? }\end{array}$ & $\begin{array}{l}\text { [Ref. } 30 \text { ] } \\
\text { [Re }\end{array}$ \\
\hline entry & 2 (equiv) $^{a}$ & additive & equiv $^{a}$ & $1(\%)^{b}$ \\
\hline 1 & 10.0 & none & & 0 \\
\hline 2 & 1.4 & $\mathrm{NaOH}$ & 0.8 & 0 \\
\hline 3 & 3.5 & $\mathrm{NaOH}$ & 2.0 & 0 \\
\hline 4 & 1.4 & $\mathrm{NaOH}$ & 3.7 & 61 \\
\hline 5 & 1.4 & $\mathrm{KOH}$ & 3.7 & 60 \\
\hline 6 & 1.4 & $\mathrm{KO}^{t} \mathrm{Bu}$ & 3.7 & 56 \\
\hline 7 & 1.4 & 2,4,6-collidin & 3.7 & 78 \\
\hline 8 & 1.4 & $\mathrm{Et}_{3} \mathrm{~N}$ & 3.7 & 66 \\
\hline 9 & 1.4 & $\mathrm{LiF}$ & 3.7 & 0 \\
\hline 10 & 1.4 & KF & 3.7 & 56 \\
\hline 11 & 1.4 & TBAF & 3.7 & 85 \\
\hline 12 & 1.4 & $\mathrm{Li}_{2} \mathrm{CO}_{3}$ & 3.7 & 78 \\
\hline 13 & 1.4 & $\mathrm{Na}_{2} \mathrm{CO}_{3}$ & 3.7 & 64 \\
\hline 14 & 1.4 & $\mathrm{~K}_{2} \mathrm{CO}_{3}$ & 3.7 & 61 \\
\hline 15 & 1.4 & $\mathrm{Li}_{2} \mathrm{CO}_{3}{ }^{c}$ & 3.7 & 86 \\
\hline
\end{tabular}

${ }^{a_{1}}$ equiv $=1 \mathrm{~mol} / \mathrm{mol}$ pure $8 .{ }^{b}$ Determined by ${ }^{1} \mathrm{H}$ NMR using 1,1,2,2-tetrachloroethane as internal standard. ${ }^{c}$ In the presence of $\mathrm{LiCl}$ (40 equiv).

efficiency, cost, and process mass intensity (entry 12), and it facilitates the isolation of the pure $\mathbf{1}$. Carbonate anions may also stabilize the multinuclear intermediates as carboxylate surrogate ligand, ${ }^{22,30}$ and the lithium salt was significantly more efficient (entries 13, 14). It was found that the presence of $\mathrm{LiCl}$ is beneficial to enhance yield and robustness of the process (entry 15), particularly in large scale reactions. This additive enhances the solubility of rhodium(III) chloride probably forming a more stable tetrachlororhodate reservoir of rhodium(III).

We recognized that esp (2) could be synthesized via the oxidative rearrangement of 1,3-diketones in basic media that our group has recently developed, ${ }^{3 \mathrm{~d}, 32}$ provided that the acyclic tetraketone intermediate 12 (Scheme $2 \mathrm{~A}$ ) would be a suitable substrate for a double rearrangement reaction. Should this be the case, the tetraketone $\mathbf{1 2}$ could be prepared from bulk acetylacetone $\left(13 ; \mathrm{p} K_{\mathrm{a}}=13\right)$ using mild inorganic bases instead of the nitrile anion $\mathbf{4}$ derived from isobutyronitrile (3; $\mathrm{p} K_{\mathrm{a}} \sim 32$ ) used in previous syntheses (Scheme 1B)..$^{11,16 a, 17,18}$ To maximize the potential of our strategy, a single-step procedure to obtain tetraketone $\mathbf{1 2}$ was developed (Scheme 2, step 1). Initial alkylation of acetylacetone (13) with methyl iodide (14) was performed using $\mathrm{K}_{2} \mathrm{CO}_{3}$ as base and acetone as solvent. ${ }^{33}$ On-scale, we found that an autoclave reactor and butanone were required to mitigate the volatility of methyl iodide in this reaction. For the second alkylation, the costeffective $m$-xylene dichloride (5b) was used in a mixture of butanone and glyme. This way, after the initial methylation was deemed complete, glyme, $\mathrm{K}_{2} \mathrm{CO}_{3}$, and $m$-xylene dichloride (5b) were added to obtain the crude $\mathbf{1 2}$ in one pot. The tetraketone $\mathbf{1 2}$ was crystallized from technical ethanol, yielding $169 \mathrm{~g}$ of 12 per batch. Surprisingly, the oxidative rearrangement of 1,3-diketones in basic media using $\mathrm{LiOH}$ and $\mathrm{H}_{2} \mathrm{O}_{2}$ that we recently developed ${ }^{3 \mathrm{~d}}$ proved completely ineffective in 
Scheme 2. Scalable Synthesis of $\mathrm{Rh}_{2} \operatorname{esp}_{2}$ (1)

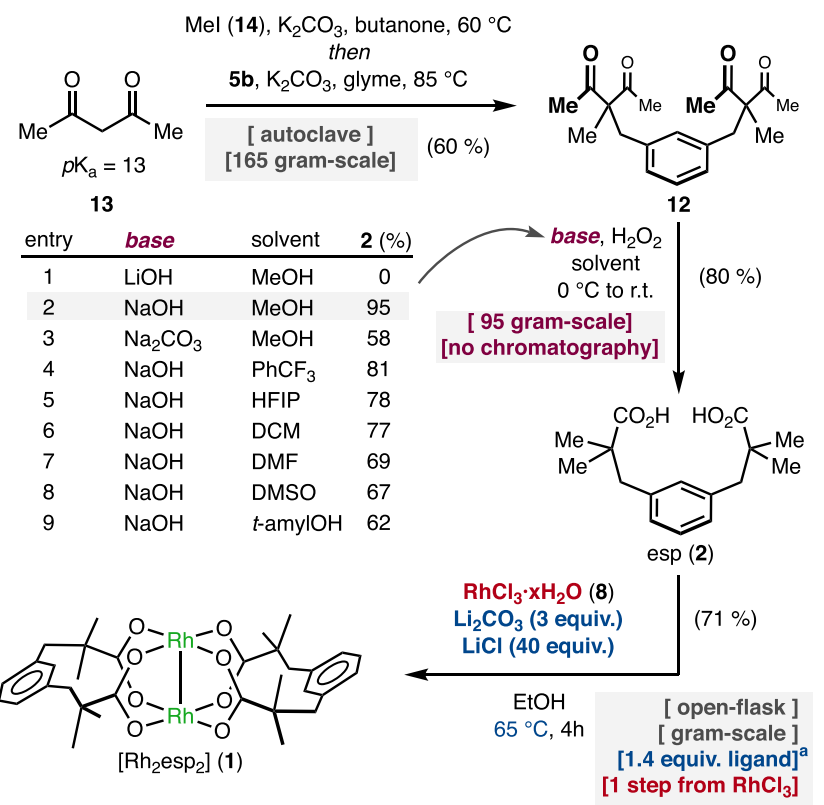

${ }^{a_{1}}$ equiv $=1 \mathrm{~mol} / \mathrm{mol}$ pure 8.

the tetraketone substrate $\mathbf{1 2}$ (entry 1). A detailed analysis of this reaction revealed quantitative retro-Claisen deacylation of the tetraketone 12, in clear contrast with our previous studies using diketones. ${ }^{3 \mathrm{~d}}$ We reasoned that the high Lewis acidity of the lithium cation may be involved in this side reaction. To our delight, it was found that replacing the base by $\mathrm{NaOH}$ suppressed this process, obtaining the doubly rearranged esp ligand (2) in excellent yield (entry 2). Interestingly, the similar carbonate base was significantly less efficient than hydroxide (entry 3 ). The reaction also occurred in a variety of solvents (entries 4-9), but none proved superior to methanol. ${ }^{34}$ Using these conditions, the tetraketone $\mathbf{1 2}$ was smoothly rearranged into esp (2) below $25{ }^{\circ} \mathrm{C}$ in large scale (Scheme 2, step 2). The product 2 could be recrystallized directly from the reaction crude to yield $95.5 \mathrm{~g}$ of esp ligand (2) in a single run. This contrasts with the limitations in scale, cost, mass intensity and safety that is inherent to nitrile anion alkylation reactions, and demonstrates for the first time the advantages of the oxidative rearrangement strategy ${ }^{3 \mathrm{~d}}$ toward congested carboxylates in process-scale.

With large quantities of esp ligand in hand, we scaled up the synthesis to produce gram quantities of $\mathrm{Rh}_{2} \operatorname{esp}_{2}(\mathbf{1})$ in a simple reflux system using technical ethanol under air (Scheme 2, step 3). ${ }^{35}$ Oxygen and moisture were found inconsequential for the efficiency of this reaction. However, a controlled ramp to steadily reach the reflux temperature (see Supporting Information) was important to obtain reproducible results. To put these results in perspective, it is important to highlight that only 1.4 equiv of the esp ligand is used, as opposed to the 90-120 equiv that was previously required with simpler carboxylic acids. ${ }^{19}$ Moreover, the catalyst is obtained for the first time in a single step from rhodium(III) chloride, thus minimizing the overall environmental impact and operational costs.

Given the particular chelate structure of the ligand esp (2), we interrogated whether it was possible to obtain with the same method other privileged monocarboxylate rhodium(II) catalysts, which are relevant in a wide range of carbene and nitrene insertion reactions. ${ }^{23-27}$ To our delight, using only marginal excess of the simple pivalic ${ }^{23}$ or octanoic ${ }^{24}$ acids under similar conditions, the corresponding complexes 15 and 16 were also produced (Scheme 3). Even the bulky

Scheme 3. Direct Preparation of $\mathrm{Rh}$ (II) Monocarboxylates from $\mathrm{RhCl}_{3} \cdot x \mathrm{H}_{2} \mathrm{O}$ and Catalyst Benchmarking Studies
A

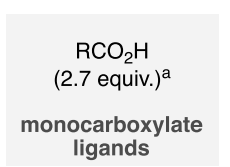

[ gram-scale ]

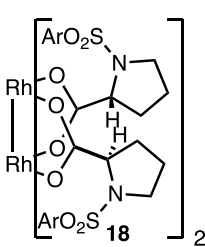

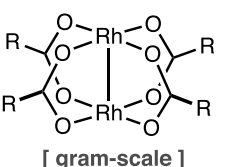
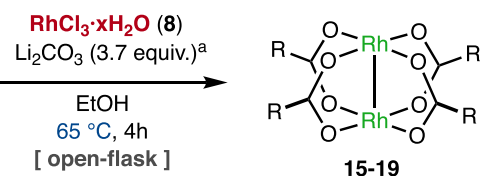

\begin{tabular}{llll} 
& \multicolumn{1}{c}{$\mathrm{R}$} & catalyst & yield $(\%)$ \\
\cline { 2 - 4 } 15 & $t$-Bu & {$\left[\mathrm{Rh}_{2}(\mathrm{Piv})_{4}\right]$} & 71 \\
16 & $n$-Oct & {$\left[\mathrm{Rh}_{2}(\mathrm{Oct})_{4}\right]$} & 67 \\
17 & $\mathrm{CPh}_{3}$ & {$\left[\mathrm{Rh}_{2}(\mathrm{TPA})_{4}\right]$} & $66^{\mathrm{b}}$
\end{tabular}

chiral catalysts

$\left[\mathrm{Rh}_{2}(\mathrm{~S}-\mathrm{TBSP})_{4}\right]$ S-18 $-57 \%$ $\left[\mathrm{Rh}_{2}(R-\mathrm{TBSP})_{4}\right]$ R-18- $52 \%$ $\left[\mathrm{Rh}_{2}(\mathrm{~S}-\mathrm{NTTL})_{4}\right]$ $19-48 \%$

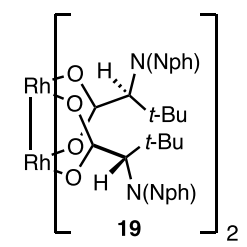

B
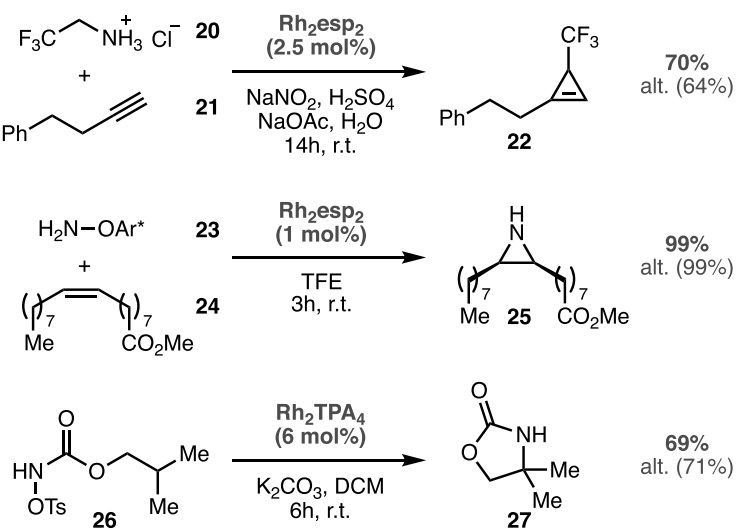

${ }^{a} 1$ equiv $=1 \mathrm{~mol} / \mathrm{mol}$ pure $8{ }^{b} 3$ equiv of $\mathrm{Li}_{2} \mathrm{CO}_{3}$ was used. Ar, 4-tertbutylphenyl; Nph, naphthalimide; alt., alternative commercial catalyst.

triphenylacetic acid yields the congested $\mathrm{Rh}_{2} \mathrm{TPA}_{4}$ catalyst $(\mathbf{1 7})^{25}$ at significantly lower temperature than through current ligand metathesis. Interestingly, these monocarboxylate catalysts 15-18 could be prepared in multigram amounts in the absence of $\mathrm{LiCl}$, unlike the chelate $\mathrm{Rh}_{2} \operatorname{esp}_{2}$ (1; Scheme 2B). The chiral monocarboxylate catalysts derived from tert-leucine and proline are widely employed in asymmetric catalysis. ${ }^{26,27}$ As representative examples, both enantiomers of $\mathrm{Rh}_{2}(\mathrm{TBSP})_{4}$ $(\mathbf{1 8})^{27}$ and the catalyst $\mathrm{Rh}_{2}(\mathrm{NTTL})_{4}(19)^{26}$ have been directly synthesized in moderate yields. Unfortunately, low efficiencies are observed using this protocol with the most extremely hindered cyclopropanecarboxylate ligands, ${ }^{35}$ probably due to unfavorable binding kinetics.

The purity of the isolated complexes synthesized using this method have been routinely assessed to be $>98 \%$ pure using ${ }^{1} \mathrm{H}$ NMR analysis (see Supporting Information). The catalytic activity of the obtained $\mathrm{Rh}_{2} \operatorname{esp}_{2}$ (1) and $\mathrm{Rh}_{2} \mathrm{TPA}_{4}$ (17) has been benchmarked against current commercial catalysts in challenging carbene and nitrene transfer reactions (Scheme 
3B). The performance of the $\mathrm{Rh}_{2} \operatorname{esp}_{2}(1)$ and $\mathrm{Rh}_{2} \mathrm{TPA}_{4}(17)$ directly prepared from $\mathrm{RhCl}_{3} \cdot x \mathrm{H}_{2} \mathrm{O}$ (8) were found to be identical to the corresponding commercial complexes in representative cyclopropenation, ${ }^{13 \mathrm{e}}$ aziridination, ${ }^{14 \mathrm{a}}$ or $\mathrm{C}-\mathrm{H}$ amination reactions. ${ }^{25 a}$

In summary, the synthesis of $\mathrm{Rh}_{2} \mathrm{esp}_{2}$ (1) has inspired the development of a mild and direct synthesis protocol from $\mathrm{RhCl}_{3} \cdot x \mathrm{H}_{2} \mathrm{O}$ using key inorganic additives to suppress overreduction to rhodium(0). This method allows important rhodium(II) catalysts to be obtained in a single operation and decreases two orders of magnitude the excess of carboxylate ligand required. Also, the alternative synthetic strategy toward the ligand esp (2) that has been presented herein demonstrates for the first time the fundamental step of oxidative rearrangement of 1,3-diketones in the process-scale production of allcarbon quaternary carboxylates. Overall, this work displays the potential of catalyst synthesis to inspire synthetic developments in both organic and inorganic chemistry.

\section{ASSOCIATED CONTENT}

\section{SI Supporting Information}

The Supporting Information is available free of charge at https://pubs.acs.org/doi/10.1021/acs.oprd.0c00164.

Synthetic procedures and characterization data (PDF)

\section{AUTHOR INFORMATION}

\section{Corresponding Author}

Abraham Mendoza - Department of Organic Chemistry, Arrhenius Laboratory, Stockholm University, 10691

Stockholm, Sweden; ㅇo이.org/0000-0001-9199-6736;

Email: abraham.mendoza@su.se

\section{Authors}

Elisa Martínez-Castro - Department of Organic Chemistry, Arrhenius Laboratory, Stockholm University, 10691 Stockholm, Sweden

Samuel Suárez-Pantiga - Department of Organic Chemistry, Arrhenius Laboratory, Stockholm University, 10691

Stockholm, Sweden; 이이.org/0000-0002-4249-7807

Complete contact information is available at:

https://pubs.acs.org/10.1021/acs.oprd.0c00164

\section{Notes}

The authors declare no competing financial interest.

\section{ACKNOWLEDGMENTS}

Financial support from the Knut and Alice Wallenberg Foundation (KAW2016.0153) and the European Research Council (714737) is gratefully acknowledged. We are indebted to the personnel of AstraZeneca Gothenburg and the Department of Organic Chemistry and the EXSELENT Center on Porous Materials at Stockholm University for unrestricted support.

\section{REFERENCES}

(1) (a) Keasling, J. D.; Mendoza, A.; Baran, P. S. A Constructive Debate - Practical Chemistry. Nature 2012, 492, 188. (b) Keding, S. J.; Danishefsky, S. J. Prospects for Total Synthesis: A Vision for a Totally Synthetic Vaccine Targeting Epithelial Tumors. Proc. Natl. Acad. Sci. U. S. A. 2004, 101, 11937. (c) Nicolaou, K. C.; Snyder, S. A. The Essence of Total Synthesis. Proc. Natl. Acad. Sci. U. S. A. 2004, 101, 11929. (d) Peterson, E. A.; Overman, L. E. Contiguous Stereogenic Quaternary Carbons: A Daunting Challenge in Natural
Products Synthesis. Proc. Natl. Acad. Sci. U. S. A. 2004, 101, 11943. (e) Nicolaou, K. C.; Hale, C. R. H.; Nilewski, C.; Ioannidou, H. A. Constructing Molecular Complexity and Diversity: Total Synthesis of Natural Products of Biological and Medicinal Importance. Chem. Soc. Rev. 2012, 41, 5185. (f) Ball, P. Chemistry: Why Synthesize? Nature 2015, 528, 327.

(2) (a) Shenvi, R. A.; O’Malley, D. P.; Baran, P. S. Chemoselectivity: The Mother of Invention in Total Synthesis. Acc. Chem. Res. 2009, 42, 530. (b) Nicolaou, K. C.; Baran, P. S. The CP Molecule Labyrinth: A Paradigm of How Endeavors in Total Synthesis Lead to Discoveries and Inventions in Organic Synthesis. Angew. Chem., Int. Ed. 2002, 41, 2678. (c) Nicolaou, K. C.; Hale, C. R. H. The Endeavor of Total Synthesis and Its Impact on Chemistry, Biology and Medicine. Natl. Sci. Rev. U.S.A. 2014, 1, 233. (d) Gutekunst, W. R.; Baran, P. S. C-H Functionalization Logic in Total Synthesis. Chem. Soc. Rev. 2011, 40, 1976.

(3) (a) Suárez-Pantiga, S.; Colas, K.; Johansson, M. J.; Mendoza, A. Scalable Synthesis of Piperazines Enabled by Visible Light Irradiation and Aluminum Organometallics. Angew. Chem., Int. Ed. 2015, 54, 14094. (b) Otero-Fraga, J.; Suarez-Pantiga, S.; Montesinos-Magraner, M.; Rhein, D.; Mendoza, A. Direct and Stereospecific $[3+2]$ Synthesis of Pyrrolidines from Simple Unactivated Alkenes. Angew. Chem., Int. Ed. 2017, 56, 12962. (c) Colas, K.; Martin-Montero, R.; Mendoza, A. Intermolecular Pummerer Coupling with Carbon Nucleophiles in Non-Electrophilic Media. Angew. Chem., Int. Ed. 2017, 56, 16042. (d) Bratt, E.; Suárez-Pantiga, S.; Johansson, M. J.; Mendoza, A. Mechanism and Regioselectivity of the Anionic Oxidative Rearrangement of 1,3-Diketones towards All-Carbon Quaternary Carboxylates. Chem. Commun. 2019, 55, 8844.

(4) For selected recent examples, see: (a) Ramírez-López, R.; Ros, A.; Romero-Arenas, A.; Iglesias-Sigüenza, J.; Fernández, R.; Lassaletta, J. M. Synthesis of IAN-type N,N-Ligands via Dynamic Kinetic Asymmetric Buchwald-Hartwig Amination. J. Am. Chem. Soc. 2016, 138, 12053. (b) Zheng, Z.; Cao, Y.; Chong, Q.; Han, Z.; Ding, J.; Luo, C.; Wang, Z.; Zhu, D.; Zhou, Q.-L.; Ding, K. Chiral Cyclohexyl-Fused Spirobiindanes: Practical Synthesis, Ligand Development, and Asymmetric Catalysis. J. Am. Chem. Soc. 2018, 140, 10374. (c) Ma, Y.-N.; Cheng, M.-X.; Yang, S.-D. Metal-Free Diastereoselective Radical Oxidative C-H Amination towards Chiral Atropoisomeric (P, N) Ligand's Precursors. Org. Lett. 2017, 19, 600.

(5) Mendoza, A.; Colas, K.; Suárez-Pantiga, S.; Goetz, D.; Johansson, M. J. Chemical Innovation through Ligand Total Synthesis. Synlett 2016, 27, 1753.

(6) (a) Labinger, J. A.; Bercaw, J. E. Understanding and Exploiting C-H Bond Activation. Nature 2002, 417, 507. (b) Brückl, T.; Baxter, R. D.; Ishihara, Y.; Baran, P. S. Innate and Guided C-H Functionalization Logic. Acc. Chem. Res. 2012, 45, 826. (c) Davies, H. M. L.; Du Bois, J.; Yu, J.-Q. C-H Functionalization in Organic Synthesis. Chem. Soc. Rev. 2011, 40, 1855. (d) White, M. C. Adding Aliphatic C-H Bond Oxidations to Synthesis. Science 2012, 335, 807.

(7) (a) Lafrance, M.; Fagnou, K. Palladium-Catalyzed Benzene Arylation: Incorporation of Catalytic Pivalic Acid as a Proton Shuttle and a Key Element in Catalyst Design. J. Am. Chem. Soc. 2006, 128, 16496. (b) Leow, D.; Li, G.; Mei, T. S.; Yu, J.-Q. Activation of Remote Meta-C-H Bonds Assisted by an End-On Template. Nature 2012, 486, 518 .

(8) For synthetic applications of $\mathrm{C}-\mathrm{H}$ functionalization, see: (a) Hinman, A.; Du Bois, J. A Stereoselective Synthesis of (-)-Tetrodotoxin. J. Am. Chem. Soc. 2003, 125, 11510. (b) Fleming, J. J.; McReynolds, M. D.; Du Bois, J. (+)-Saxitoxin: A First and Second Generation Stereoselective Synthesis. J. Am. Chem. Soc. 2007, 129, 9964. (c) Mulcahy, J. V.; Du Bois, J. A Stereoselective Synthesis of (+)-Gonyautoxin 3. J. Am. Chem. Soc. 2008, 130, 12630. (d) Gutekunst, W. R.; Baran, P. S. Total Synthesis and Structural Revision of the Piperarborenines via Sequential Cyclobutane $\mathrm{C}-\mathrm{H}$ Arylation. J. Am. Chem. Soc. 2011, 133, 19076. (e) Noisier, A. F. M.; Brimble, M. A. C-H Functionalization in the Synthesis of Amino Acids and Peptides. Chem. Rev. 2014, 114, 8775. (f) Wilde, N. C.; 
Isomura, M.; Mendoza, A.; Baran, P. S. Two-Phase Synthesis of (-)-Taxuyunnanine D. J. Am. Chem. Soc. 2014, 136, 4909.

(9) (a) Du Bois, J. Rhodium-Catalyzed C-H Amination. An Enabling Method for Chemical Synthesis. Org. Process Res. Dev. 2011, 15 (4), 758. (b) Zatolochnaya, O. V.; Gevorgyan, V. The Road Less Travelled to Amination. Nat. Chem. 2014, 6, 661.

(10) For a recent $\mathrm{C}-\mathrm{H}$ amination of arenes, see: Paudyal, M. P.; Adebesin, M. A.; Burt, S. R.; Ess, D. H.; Ma, Z.; Kürti, L. DirhodiumCatalyzed $\mathrm{C}-\mathrm{H}$ Arene Amination using Hydroxylamines. Science 2016, 353, 1144.

(11) Espino, C. G.; Fiori, K. W.; Kim, M.; Du Bois, J. Expanding the Scope of C-H Amination through Catalyst Design. J. Am. Chem. Soc. 2004, 126, 15378.

(12) (a) Zalatan, D. N.; Du Bois, J. Understanding the Differential Performance of Rh2(esp) 2 as a Catalyst for $\mathrm{C}-\mathrm{H}$ Amination. J. Am. Chem. Soc. 2009, 131, 7558. (b) Das, A.; Maher, A. G.; Telser, J.; Powers, D. C. Observation of a Photogenerated $\mathrm{Rh}_{2}$ Nitrenoid Intermediate in C-H Amination. J. Am. Chem. Soc. 2018, 140 (33), 10412. (c) Varela-Álvarez, A.; Yang, T.; Jennings, H.; Kornecki, P.; Macmillan, S. N.; Lancaster, K. M.; Mack, J. B. C.; Du Bois, J.; Berry, J. F.; Musaev, D. G. $\mathrm{Rh}_{2}$ (II, III) Catalysts with Chelating Carboxylate and Carboxamidate Supports: Electronic Structure and Nitrene Transfer Reactivity. J. Am. Chem. Soc. 2016, 138 (7), 2327. (d) Das, A.; Chen, Y.-S.; Reibenspies, J. H.; Powers, D. C. Characterization of a Reactive $\mathrm{Rh}_{2}$ Nitrenoid by Crystalline Matrix Isolation. J. Am. Chem. Soc. 2019, 141, 16232.

(13) For applications of $\mathbf{1}$ in carbene transfer reactions, see: (a) Dao, H. T.; Baran, P. S. Quinone Diazides for Olefin Functionalization. Angew. Chem., Int. Ed. 2014, 53, 14382. (b) Shi, Y.; Gulevich, A. V.; Gevorgyan, V. Rhodium-Catalyzed NH Insertion of Pyridyl Carbenes Derived from Pyridotriazoles: A General and Efficient Approach to 2Picolylamines and Imidazo[1,5-a]pyridines. Angew. Chem., Int. Ed. 2014, 53, 14191. (c) Karageorgis, G.; Warriner, S.; Nelson, A. Efficient discovery of bioactive scaffolds by activity-directed synthesis. Nat. Chem. 2014, 6, 872. (d) Shi, Y.; Gulevich, A. V.; Gevorgyan, V. Rhodium-Catalyzed NH Insertion of Pyridyl Carbenes Derived from Pyridotriazoles: A General and Efficient Approach to 2-Picolylamines and Imidazo[1,5-a $]$ pyridines. Angew. Chem., Int. Ed. 2014, 53, 14191. (e) Morandi, B.; Carreira, E. M. Rhodium-Catalyzed Cyclopropenation of Alkynes: Synthesis of Trifluoromethyl-Substituted Cyclopropenes. Angew. Chem., Int. Ed. 2010, 49, 4294.

(14) For applications of $\mathbf{1}$ in nitrene transfer reactions beyond $\mathrm{C}-\mathrm{H}$ amination, see: (a) Jat, J. L.; Paudyal, M. P.; Gao, H.; Xu, Q. L.; Yousufuddin, M.; Devarajan, D.; Ess, D. H.; Kürti, L.; Falck, J. R. Direct and Stereospecific Synthesis of Unprotected N-H and N-Me Aziridines from Olefins. Science 2014, 343, 61. (b) Ma, Z.; Zhou, Z.; Kürti, L. Direct and Stereospecific Synthesis of N-H and N-Alkyl Aziridines from Unactivated Olefins Using Hydroxylamine-O-Sulfonic Acids. Angew. Chem., Int. Ed. 2017, 56, 9886. (c) Zhou, Z.; Cheng, Q.Q.; Kürti, L. Aza-Rubottom Oxidation: Synthetic Access to Primary $\alpha$-Aminoketones. J. Am. Chem. Soc. 2019, 141, 2242.

(15) For applications of $\mathbf{1}$ in oxidation reactions, see: (a) Wang, Y.; Kuang, Y.; Zhang, H.; Ma, R.; Wang, Y. Recyclable Dirhodium(II) Catalyst $\mathrm{Rh}_{2}(\mathrm{esp})_{2}$ for the Allylic Oxidation of $\Delta 5$-Steroids. J. Org. Chem. 2017, 82, 4729. (b) Zhao, L.; Zhang, H.; Wang, Y. Dirhodium(II)-Catalyzed Sulfide Oxygenations: Catalyst Removal by Coprecipitation with Sulfoxides. J. Org. Chem. 2016, 81, 129.

(16) For palladium, see: (a) Powers, D. C.; Ritter, T. Bimetallic $\mathrm{Pd}(\mathrm{III})$ Complexes in Palladium-Catalysed Carbon-Heteroatom Bond Formation. Nat. Chem. 2009, 1, 302. (b) Powers, D. C.; Benitez, D.; Tkatchouk, E.; Goddard, W. A.; Ritter, T. Bimetallic Reductive Elimination from Dinuclear Pd(III) Complexes. J. Am. Chem. Soc. 2010, 132, 14092. For rhenium, see: (c) Dequeant, M. Q.; Fanwick, P. E.; Ren, T. Synthesis and Structural Characterization of Several Dirhenium(III) Compounds. Inorg. Chim. Acta 2006, 359, 4191. For ruthenium, see: (d) Barker, J. E.; Ren, T. Diruthenium(II, III) Bis(tetramethyl-1,3-benzenedipropionate) as a Novel Catalyst for tert-Butyl Hydroperoxide Oxygenation. Inorg. Chem. 2008, 47, 2264. (e) Harvey, M. E.; Musaev, D. G.; Du Bois, J. A Diruthenium Catalyst for Selective, Intramolecular Allylic $\mathrm{C}-\mathrm{H}$ Amination: Reaction Development and Mechanistic Insight Gained through Experiment and Theory. J. Am. Chem. Soc. 2011, 133, 17207. For copper, see: (f) Tnay, Y. L.; Chen, C.; Chua, Y. Y.; Zhang, L.; Chiba, S. CopperCatalyzed Aerobic Spirocyclization of Biaryl-N-H-imines via 1,4Aminooxygenation of Benzene Rings. Org. Lett. 2012, 14, 3550. For cobalt, see: (g) Pakula, R. J.; Berry, J. F. Cobalt Complexes of the Chelating Dicarboxylate Ligand "Esp": a Paddlewheel-Type Dimer and a Heptanuclear Coordination Cluster. Dalton Trans. 2018, 47, 13887. For bismuth-rhodium heteroleptic catalysts, see: (h) Collins, L. R.; van Gastel, M.; Neese, F.; Fürstner, A. Enhanced Electrophilicity of Heterobimetallic Bi-Rh Paddlewheel Carbene Complexes: A Combined Experimental, Spectroscopic, and Computational Study. J. Am. Chem. Soc. 2018, 140, 13042.

(17) (a) Kornecki, K. P.; Berry, J. F. Introducing a Mixed-Valent Dirhodium(II, III) Catalyst with Increased Stability in $\mathrm{C}-\mathrm{H}$ Amination. Chem. Commun. 2012, 48, 12097. (b) Kornecki, K. P.; Berry, J. F. Dirhodium Catalysts That Bear Redox Noninnocent Chelating Dicarboxylate Ligands and Their Performance in Intra- and Intermolecular C-H Amination. Eur. J. Inorg. Chem. 2012, 2012, 562.

(18) Fukazawa, Y.; Usui, S.; Tanimoto, K.; Hirai, Y. Conformational Analysis by the Ring Current Method. The Structure of 2,2,13,13Tetramethyl[4.4]metacyclophane. J. Am. Chem. Soc. 1994, 116, 8169.

(19) (a) Rempel, G. L.; Legzdins, P.; Smith, H.; Wilkinson, G. Tetrakis(acetato)dirhodium(II) and Similar Carboxylato Compounds. Inorg. Synth. 2007, 13, 90. (b) Legzdins, P.; Mitchell, R. W.; Rempel, G. L.; Ruddick, J. D.; Wilkinson, G. The Protonation of Ruthenium- and Rhodium-Bridged Carboxylates and their Use as Homogeneous Hydrogenation Catalysts for Unsaturated Substances. J. Chem. Soc. A 1970, 3322. (c) Drago, R. S.; Cosmano, R.; Telser, J. EPR spectra and Bonding in the 2:1 Base Adducts of $\mathrm{Rh}_{2}(\text { carboxylate })^{4+}$. Inorg. Chem. 1984, 23, 3120. (d) Effective preparation using only acetic acid has also been reported (see ref 22a). For preparation from $\mathrm{Rh}(\mathrm{OH})_{3} \cdot \mathrm{H}_{2} \mathrm{O}$, see: (e) Johnson, S.; Hunt, H. R.; Neumann, H. M. Preparation and Properties of Anhydrous Rhodium(II) Acetate and Some Adducts Thereof. Inorg. Chem. 1963, 2, 960. For a seminal preparation from $\mathrm{Rh}_{2} \mathrm{O}_{3}$ and acetic acid, see: (f) Stephenson, T. A.; Morehouse, S. M.; Powell, A. R.; Heffer, J. P.; Wilkinson, G. Carboxylates of Palladium, Platinum, And Rhodium, and their Adducts. J. Chem. Soc. 1965, 3632.

(20) For the synthesis of $\mathrm{Rh}(\mathrm{I})$ catalysts, see: (a) Osborn, J. A.; Jardine, F. H.; Young, J. F.; Wilkinson, G. The Preparation and Properties of Tris(triphenylphosphine)halogenorhodium(I) and Some Reactions Thereof Including Catalytic Homogeneous Hydrogenation of Olefins and Acetylenes and Their Derivatives. J. Chem. Soc. A 1966, 1711. Osborn, J. A.; Wilkinson, G. Tris(Triphenylphosphine)Halorhodium(I). Inorg. Synth. 2007, 10, 67. (c) Giordano, G.; Crabtree, R. H. Di- $\mu$-chloro-bis $(\eta 4-1,5-$ cyclooctadiene)dirhodium(I). Inorg. Synth. 2007, 28, 88. For the synthesis of $\mathrm{Cp} * \mathrm{Rh}(\mathrm{III})$ catalysts, see: (d) Herrmann, W. A.; Zybill, C $\operatorname{Bis}\{(\mu$-chloro $)$ [chloro $(\eta$-pentamethylcyclopentadienyl $)$ rhodium $]$. In Synthetic Methods of Organometallic and Inorganic Chemistry - Vol. 1: Literature, Laboratory Techniques, and Common Starting Materials; Herrmann, W. A., Salzer, A., Eds.; Georg Thieme Verlag, pp 148. (e) White, C.; Yates, A.; Maitlis, P. M. ( $\eta 5$ Pentamethylcyclopentadienyl)Rhodium and -Iridium Compounds. Inorg. Synth. 2007, 29, 228.

(21) (a) Montesinos-Magraner, M.; Costantini, M.; RamirezContreras, R.; Muratore, M.; Johansson, M. J.; Mendoza, A. General Cyclopropane Assembly via Enantioselective Transfer of a RedoxActive Carbene to Aliphatic Olefins. Angew. Chem., Int. Ed. 2019, 58, 5930. (b) Yu, Z.; Mendoza, A. Enantioselective Assembly of Congested Cyclopropanes using Redox-Active Aryldiazoacetates. ACS Catal. 2019, 9, 7870.

(22) For dirhodium(II) complexes of the carbonate anion, see: (a) Wilson, C. R.; Taube, H. New Complexes of Dirhodium(II). Inorg. Chem. 1975, 14, 405. The dirhodium(II) carbonate $\mathrm{Na}_{4}\left[\mathrm{Rh}_{2}\left(\mathrm{CO}_{3}\right)_{4}\right]$ is prepared from $\mathrm{Rh}_{2}(\mathrm{OAc})_{4}$ and used in the synthesis of complexes through thermal ligand metathesis, see: 
(b) Roos, G. H. P.; McKervey, M. A. A Facile Synthesis of Homochiral Rh(II) Carboxylates. Synth. Commun. 1992, 22, 1751.

(23) For synthesis and applications of $\mathrm{Rh}_{2} \mathrm{Piv}_{4}$, see: (a) Miura, T.; Funakoshi, Y.; Murakami, M. Intramolecular Dearomatizing [3 + 2] Annulation of $\alpha$-Imino Carbenoids with Aryl Rings Furnishing 3,4Fused Indole Skeletons. J. Am. Chem. Soc. 2014, 136, 2272. (b) Zibinsky, M.; Fokin, V. V. Sulfonyl-1,2,3-Triazoles: Convenient Synthones for Heterocyclic Compounds. Angew. Chem., Int. Ed. 2013, 52, 1507. (c) DeAngelis, A.; Taylor, M. T.; Fox, J. M. Unusually Reactive and Selective Carbonyl Ylides for Three-Component Cycloaddition Reactions. J. Am. Chem. Soc. 2009, 131, 1101. (d) Chen, K.; Zhu, Z.-Z.; Zhang, Y.-S.; Tang, X.-Y.; Shi, M. Rhodium(II)-Catalyzed Intramolecular Cycloisomerizations of Methylenecyclopropanes with $N$-Sulfonyl 1,2,3-Triazoles. Angew. Chem., Int. Ed. 2014, 53, 6645.

(24) For late-stage functionalization of complex molecules using $\mathrm{Rh}_{2} \mathrm{Oct}_{4}$, see: (a) He, J.; Hamann, L. G.; Davies, H. M. L.; Beckwith, R. E. J. Late-stage C-H Functionalization of Complex Alkaloids and Drug Molecules Via Intermolecular Rhodium-Carbenoid Insertion. Nat. Commun. 2015, 6, 5943. For an early-stage multi-gram scale NH-insertion in total synthesis, see: (b) Malinowski, J. T.; Sharpe, R. J.; Johnson, J. S. Enantioselective Synthesis of Pactamycin, a Complex Antitumor Antibiotic. Science 2013, 340, 180. For an early-stage vinylcarbene cycloaddition in total synthesis, see: For creative azavinyl carbene methods, see: (c) Jackson, K. L.; Henderson, J. A.; Motoyoshi, H.; Phillips, A. J. A Total Synthesis of Norhalichondrin B. Angew. Chem., Int. Ed. 2009, 48, 2346. (d) Chuprakov, S.; Worrell, B. T.; Selander, N.; Sit, R. K.; Fokin, V. V. Stereoselective 1,3Insertions of Rhodium(II) Azavinyl Carbenes. J. Am. Chem. Soc. 2014, 136, 195. (f) Selander, N.; Worrell, B. T.; Fokin, V. V. Ring Expansion and Rearrangements of Rhodium(II) Azavinyl Carbenes. Angew. Chem., Int. Ed. 2012, 51, 13054.

(25) For synthesis and applications of $\mathrm{Rh}_{2} \mathrm{TPA}_{4}$, see: (a) Lebel, $\mathrm{H}$.; Huard, K.; Lectard, S. N-Tosyloxycarbamates as a Source of Metal Nitrenes: Rhodium-Catalyzed $\mathrm{C}-\mathrm{H}$ Insertion and Aziridination Reactions. J. Am. Chem. Soc. 2005, 127, 14198. (b) Hashimoto, S.; Watanabe, N.; Ikegami, S. Dirhodium(II) Tetra(Triphenylacetate): A Highly Efficient Catalyst for the Site-Selective Intramolecular $\mathrm{C}-\mathrm{H}$ Insertion Reactions of $\alpha$-Diazo $\beta$-Keto Esters. Tetrahedron Lett. 1992, 33, 2709. (c) Yu, Z.; Pan, Y.; Wang, Z.; Wang, J.; Lin, Q. Genetically Encoded Cyclopropene Directs Rapid, Photoclick-Chemistry-Mediated Protein Labeling in Mammalian Cells. Angew. Chem., Int. Ed. 2012, 51, 10600. (d) Lindsay, V. N. G.; Viart, H. M.-F.; Sarpong, R. Stereodivergent Intramolecular $\mathrm{C}\left(s p^{3}\right)-\mathrm{H}$ Functionalization of Azavinyl Carbenes: Synthesis of Saturated Heterocycles and Fused N-Heterotricycles. J. Am. Chem. Soc. 2015, 137, 8368. (e) Guo, J.-X.; Zhou, T.; Xu, B.; Zhu, S.-F.; Zhou, Q.-L. Enantioselective Synthesis of $\alpha$-Alkenyl A-Amino Acids Via N-H Insertion Reactions. Chem. Sci. 2016, 7, 1104. (f) Gerstner, N. C.; Adams, C. S.; Tretbar, M.; Schomaker, J. M. Stereocontrolled Syntheses of Seven-Membered Carbocycles by Tandem Allene Aziridination/ $[4+3]$ Reaction. Angew. Chem., Int. Ed. 2016, 55, 13240.

(26) (1) Müller, P.; Allenbach, Y. F.; Robert, E. Rhodium(II)Catalyzed Olefin Cyclopropanation with the phenyliodonium Ylide Derived from Meldrum's Acid. Tetrahedron: Asymmetry 2003, 14, 779. (a) DeAngelis, A.; Shurtleff, V. W.; Dmitrenko, O.; Fox, J. M. Rhodium(II)-Catalyzed Enantioselective C-H Functionalization of Indoles. J. Am. Chem. Soc. 2011, 133, 1650. (b) Adly, F. G.; Maddalena, J.; Ghanem, A. $\mathrm{Rh}_{2}(S-1,2-\mathrm{NTTL})_{4}$ : A novel $\mathrm{Rh}_{2}(S$ PTTL $)_{4}$ Analog With Lower Ligand Symmetry for Asymmetric Synthesis of Chiral Cyclopropylphosphonates. Chirality 2014, 26, 764-774. (c) Yadagiri, D.; Reddy, A. C. S.; Anbarasan, P. Rhodium Catalyzed Diastereoselective Synthesis of 2,2,3,3-Tetrasubstituted Indolines from $\mathrm{N}$-Sulfonyl-1,2,3-Triazoles and ortho-Vinylanilines. Chem. Sci. 2016, 7, 5934. (d) Kubiak, R. W.; Davies, H. M. L. Rhodium-Catalyzed Intermolecular $\mathrm{C}-\mathrm{H}$ Functionalization as a Key Step in the Synthesis of Complex Stereodefined $\beta$-Arylpyrrolidines. Org. Lett. 2018, 20, 3771.
(27) For synthesis and applications of $\mathrm{Rh}_{2}(\mathrm{TBSP})_{4}$, see: (a) Davies, H. M. L.; Peng, Z.-Q.; Houser, J. H. Asymmetric Synthesis of 1,4Cycloheptadienes and Bicyclo[3.2.1] octa-2,6-dienes by Rhodium(II) $\mathrm{N}$-( $p$-(tert-butyl)-phenylsulfonyl)prolinate Catalyzed Reactions between Vinyldiazomethanes and Dienes. Tetrahedron Lett. 1994, 35, 8939. (b) Davies, H. M. L.; Walji, A. M.; Nagashima, T. Simple Strategy for the Immobilization of Dirhodium Tetraprolinate Catalysts using a Pyridine-Linked Solid Support. J. Am. Chem. Soc. 2004, 126, 4271. (c) Our group has recently used $\mathrm{Rh}_{2}(\mathrm{TBSP})_{4}$ in the scalable asymmetric synthesis of the congested TPCP ligand (see ref 21b).

(28) Harris, D. C. Quantitative Chemical Analysis, 8th ed.; W.H. Freeman \& Co, 2010; p AP25.

(29) For a study on the variation of the redox-potential with $\mathrm{pH}$, see: Pourbaix, M. J. N.; Van Muylder, J.; de Zoubov, N. Electrochemical Properties of the Platinum Metals. Platinum Metals Rev. 1959, 3, 100.

(30) Kataoka, Y.; Yano, N.; Kawamoto, T.; Handa, M. Isolation of a Tetranuclear Intermediate Complex in the Synthesis of PaddlewheelType Dirhodium Tetraacetate. Eur. J. Inorg. Chem. 2015, 2015, 5650.

(31) Rhodium nanoparticles can be synthesized by reduction in basic ethanol: Li, F.; Weng, H.; Shang, Y.; Ding, Z.; Yang, Z.; Cheng, S.; Lin, M. Environmentally Friendly and Facile Synthesis of Rh Nanoparticles at Room Temperature by Alkaline Ethanol Solution and their Application for Ethanol Electrooxidation. RSC Adv. 2017, 7, 3161.

(32) For seminal work in the oxidative rearrangement of 1,3diketones, see: (a) Mannich, C. Über die $\alpha . \alpha ; \alpha^{\prime} . \alpha^{\prime}$-Bis-[Tetramethylen]-Adipinsäure. Ein Fall von Ringverengerung durch Oxydation. Ber. Dtsch. Chem. Ges. B 1941, 74, 1007. (b) Payne, G. B. Reactions of Hydrogen Peroxide. X. Oxidative Rearrangements with Certain $\beta$ Diketones. J. Org. Chem. 1961, 26, 4793. (c) Cocker, W.; Grayson, D. H. Reactions of Some Dicarbonyl Compounds. Part III. Oxidation of some $\beta$-Diketones with Alkaline Hydrogen Peroxide. J. Chem. Soc., Perkin Trans. 1 1975, 1347.

(33) (a) Johnson, A. W.; Markham, E.; Price, R. 3-Methylpentane2,4-Dione. Org. Synth. 1962, 42, 75. (b) Kalaitzakis, D.; Rozzell, J. D.; Smonou, I.; Kambourakis, S. Synthesis of Valuable Chiral Intermediates by Isolated Ketoreductases: Application in the Synthesis of $\alpha$-Alkyl- $\beta$-hydroxy Ketones and 1,3-Diols. Adv. Synth. Catal. 2006, 348, 1958.

(34) In acetonitrile, extensive deacylation of the substrate was observed.

(35) (a) Qin, C.; Boyarskikh, V.; Hansen, J. H.; Hardcastle, K. I.; Musaev, D. G.; Davies, H. M. L. D ${ }_{2}$-Symmetric Dirhodium Catalyst Derived from a 1,2,2-Triarylcyclopropanecarboxylate Ligand: Design, Synthesis and Application. J. Am. Chem. Soc. 2011, 133, 19198. (b) Qin, C.; Davies, H. M. L. $\mathrm{Rh}_{2}(R \text {-TPCP })_{4}$-Catalyzed Enantioselective $[3+2]$-Cycloaddition between Nitrones and Vinyldiazoacetates. J. Am. Chem. Soc. 2013, 135, 14516. (c) Qin, C.; Davies, H. M. L. Role of Sterically Demanding Chiral Dirhodium Catalysts in SiteSelective C-H Functionalization of Activated Primary C-H Bonds. J. Am. Chem. Soc. 2014, 136, 9792. (d) Liao, K.; Negretti, S.; Musaev, D.; Bacsa, J.; Davies, H. M. L. Site-Selective and Stereoselective Functionalization of Unactivated C-H Bonds. Nature 2016, 533, 230. (e) Our group has recently applied this family in asymmetric cyclopropanations with redox-active carbenes (see ref $21 \mathrm{~b}$ ). 